\title{
Emphysema of Neck Following Oral Cavity Trauma- Case Report
}

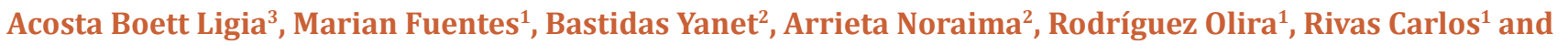 \\ Delgado Beatriz ${ }^{1}$ \\ 1Residente del Postgrado de Otorrinolaringología. Hospital de Niños "Dr. José Manuel de los Ríos", South America
}

2Adjunto del Servicio de Otorrinolaringología. Hospital de Niños “Dr. José Manuel de los Ríos”, South America

3Jefe de Servicio de Otorrinolaringología. Hospital de Niños “Dr. José Manuel de los Ríos”, South America

Submission: February 16, 2017; Published: March 03, 2017

*Corresponding author: Acosta Boett Ligia, Jefe de Servicio de Otorrinolaringología. Hospital de Niños “Dr. José Manuel de los Ríos”,

Vicepresidenta de la Junta Directiva SVORL, Venezuela, South America, Email: ligiaorl2@gmail.com

Abstract

Introduction: Emphysema is a swelling caused by the penetration of air or gas in the subcutaneous or submucosal tissues. Etiology can betraumatic, iatrogenic or spontaneous. When the anatomic site involved committed neck spaces, you can dissect extensive muscle-fascial planes, like the deep spaces of the neck and mediastinum. The clinic is variable, it depends on the location involved, can manifest as a slight sore throat, respiratory distress, stridor or snoring, chest pain if pneumomediastinum, causing significant symptoms of hemodynamic and respiratory decompensation.

Case: Male 06 years old, born and from the town, who after oral trauma with blunt object (umbrella) School presents oral cavity bleeding, sore throat and progressive dysphagia drooling with cervical pain and functional limitation neck movements; without respiratory distress. $\mathrm{Rx}$ neck and chest is made where retropharyngeal emphysema reaching pericardium through the mediastinum evidence. In CT scan of neck extension thorax air is evident in paravertebral spaces, bilateral parapharyngeal and towards the base of the neck with small bubbles dissect the plane of the thyroid gland, vascular structures and predominance of left upper mediastinum level, reason by which it is entered with continuous monitoring of respiratory and internal environment, prophylactic antibiotics and analgesia, evolving satisfactorily, without complications.

Conclusion: Emphysema in neck deep spaces are rare. In most cases spontaneously reabsorbed emphysema, however, the patient must be kept under observation to reduce complications; Likewise administration of analgesia and prophylactic antibiotic therapy.

Keywords: Parapharyngealemphysema; Trauma; Pneumomediastinum

\section{Introduction}

The term emphysema comes from the Greek word "emphysan" and means "to blow inside". Emphysema is a swelling produced by the penetration of air or gas into the subcutaneous or submucosal tissues. According to the medical record of the Dominican Republic, I reported an incidence of 0.8 per 1000 inhabitants, with a male prevalence between the ages of 3 to 70 years. The etiology of emphysema can be traumatic of the blunt, punctured, and punctured type involving structures at the neck (trachea, larynx, esophagus) and thorax; The most common cause is maxillary surgery and dental procedures (extractions, endodoncias and cleanings), the most outstanding being the extraction of the $3^{\text {rd }}$ molar, difficult intubations, spontaneous tonsillectomy Such as Boerhaave Syndrome, seizures, inflating a balloon, all these causes include abnormal air pressures. When the compromised anatomical site involves the spaces of the neck, it can dissect extensive muscular-aponeurotic planes, such as the deep spaces of the neck and the mediastinum [1-6].

The neck has fascias that define the spaces that limit to some extent the spread of infections and tumors. These spaces include the retropharyngeal space that is previously delimited by the buccopharyngeal fascia and later by the prevertebral fascia, extending from the base of the skull to the anterior mediastinum. The clinical presentationis variable, depending on the place involved, may manifest as slight odynophagia, respiratory distress, stridor or snoring, retrosternal pain in case of pneumomediastinum, causing important hemodynamic and respiratory decompensation symptoms. The most common initial diagnostic method is the chest x-ray, where the presence 


\section{Global Journal of Otolaryngology}

of air can be observed by dissecting the deep spaces of the neck that may even extend to the mediastinum, as well as a CT scan of the neck with an extension to the neck which is more specific, it is possible to visualize the location, extension and precise characteristics of the lesion [7-10].

The behavior to be followed will depend on the extent of the emphysema and its severity, since in most cases it is spontaneously resorbed. Conservative therapy based on internal and respiratory monitoring, anti-inflammatory, and prophylactic antibiotic therapy for gram (+) germs mainly, this issue has been discussed by different authors, without reaching a total consensus. When symptoms are more severe, a multidisciplinary approach should be performed with the services associated with complications, eg: pulmonology, cardiology, chest surgery, even in more extreme cases. General surgery in the case of pneumoperitoneum, Dr. Petersilka in the year 2011, in its publication in the journal of the Spanish Society of Periodontics and Osseointegration, poses the following algorithm for the management of cervical emphysema.

\section{Clinical Case}

A 6-year-old male, natural and from the locality, who after oral trauma with a blunt tip (umbrella) has oral cavity bleeding, odynophagia and dysphagia. Progressive, sialorrhoea, with pain in cervical region and functional limitation in movements of the neck; Without respiratory difficulty.

\section{Examination}

a) FC: $125 \mathrm{lpm}$ TA: 109/81 S02: 98 -99\% P: $28.5 \mathrm{Kg}$

b) Stable clinical conditions: examination of ear and nose revealed no abnormality.

c) Bifid uvula with blood remains. Tonsils grade III / IV. Oropharyngeal wall without lesions.

d) Neck: short without volume increase, central trachea, thyroid 0 degree. Erythema in right lateral triangle is evident in posterior border of the ECM, as well as pain to lateralization movements.

e) Cardiopulmonary: normoexpansible symmetrical thorax, audible MV in both pulmonary fields without aggregates. RsCsRsnormofonéticos no murmurs.

Nasofibrolaryngoscopy is carried out where no lesion or stigma of the same is evidenced, or hematic remains. $\mathrm{Rx}$ of the neck and thorax where retropharyngeal emphysema is found that reaches the pericardium through the mediastinum (Figures 1 \& 2). In computerized tomography of the neck with chest extension air is evident in paravertebral, bilateral parapharyngeal spaces and towards the base of the neck with small bubbles that dissect the plane of the thyroid gland, vascular structures predominating on the left side and at the level of the upper mediastinum (Figures 3-6).
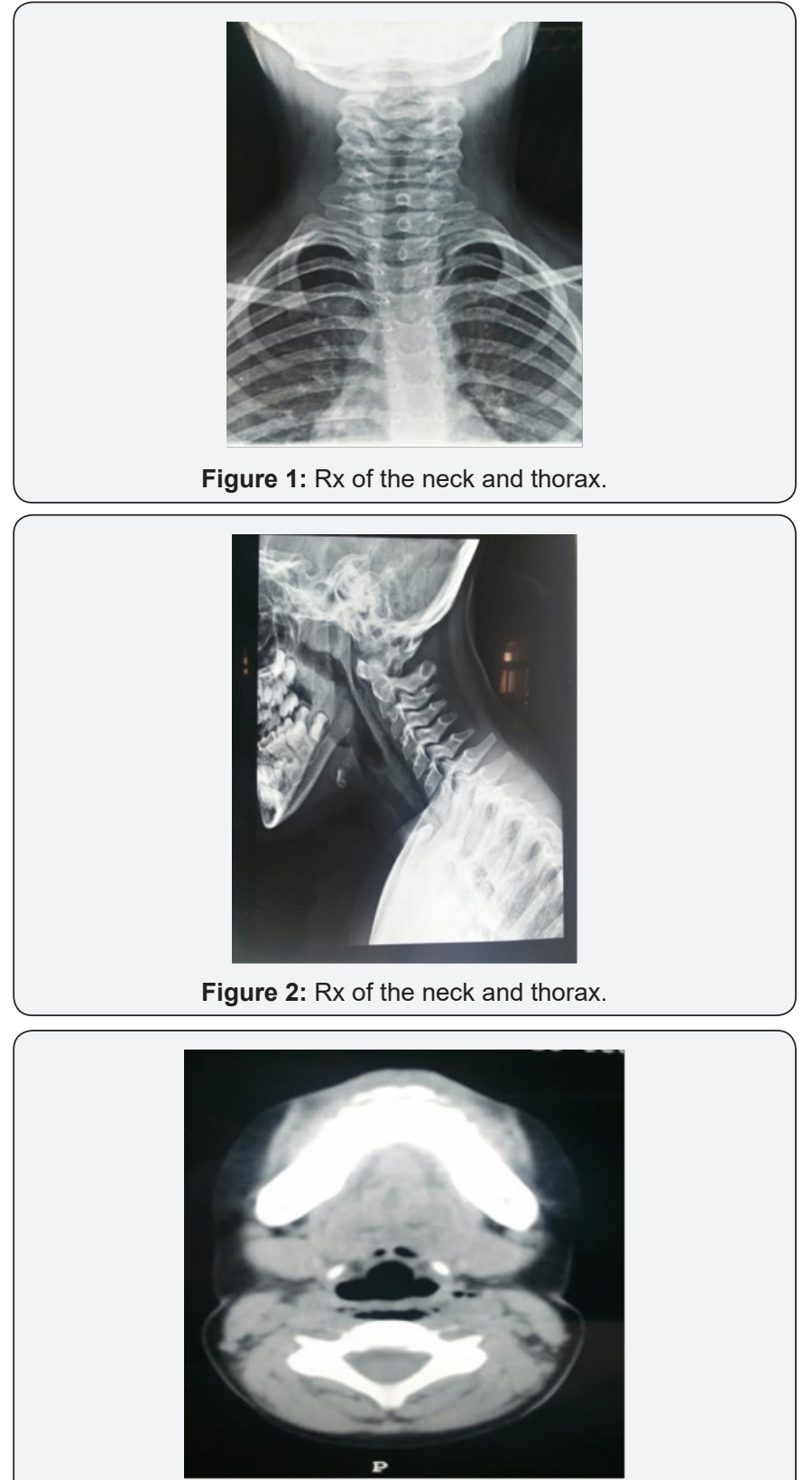

Figure 3: Computerized tomography of the neck with chest extension.

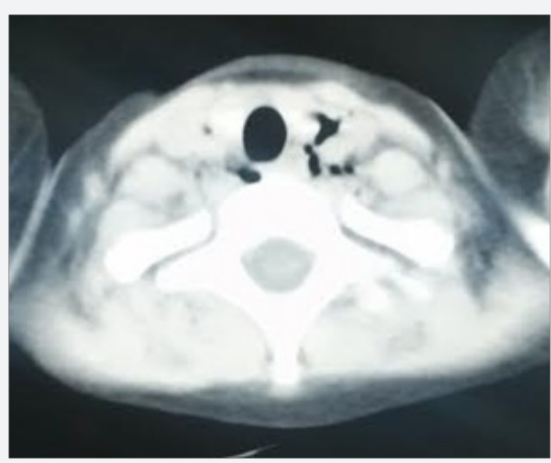

Figure 4: Computerized tomography of the neck with chest extension. 


\section{Global Journal of Otolaryngology}

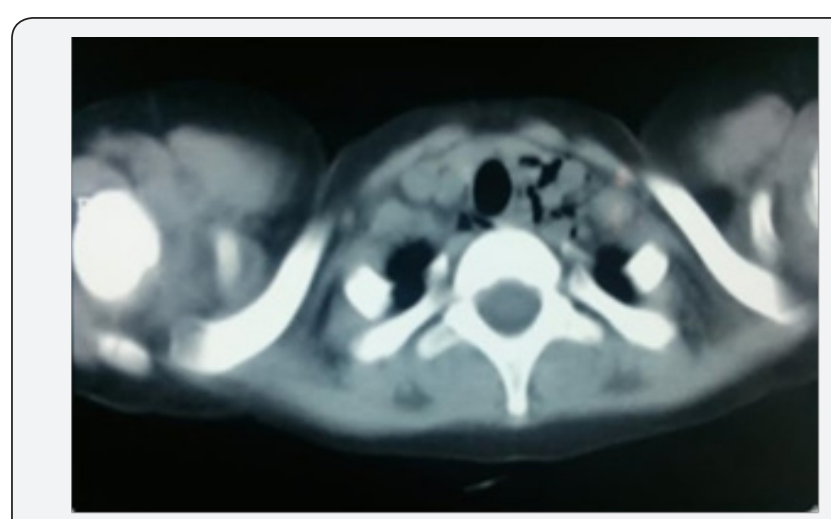

Figure 5: Computerized tomography of the neck with chest extension.

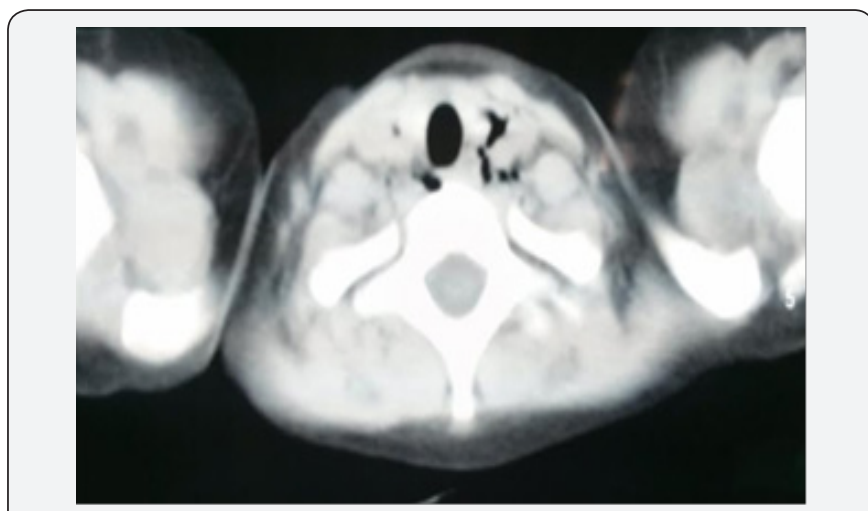

Figure 6: Computerized tomography of the neck with chest extension.

It is evaluated by the service of Thorax and Pneumonology Surgery who in view of the findings in the imaging studies, the diagnosis of: Trauma of oral cavity complicated with parapharyngeal emphysema and pneumomediastinum; And antibiotic prophylaxis with ampicillin / sulbactan $100 \mathrm{mg} / \mathrm{kg}$ / day and anti-inflammatory with Dexamethasone 0.6mg / kg / day for 72 hours and ketoprofen $1 \mathrm{mg}$ / kg / dose, oxygen By mask;satisfactorily, without complications.

\section{Discussion}

Report that subcutaneous emphysema in the neck is not infrequent in our specialty. In many spontaneous, accidental or surgical situations air can appear in the cervical spaces, being the most frequent cause the maxillary surgeries and dental procedures (extractions, endodoncias and cleanings), however the progression of air or gas towards the mediastinum is exceptional. The behavior for this entity is determined according to the patient's symptoms and extent of emphysema, however, emphysema in most cases is resolved spontaneously. The most commonly used behavior is wet oxygen to accelerate air reabsorption and increase air pressure. $\mathrm{O}_{2}$ in the tissue. Analgesia to reduce pain; The use of prophylactic antibiotics is a topic of debate, although there are no detailed trials of it, the use of these to prevent possible infections, recommend oral or intravenous antibiotics as derivatives of penicillin (amoxicillin, ampicillin), cephalosporins or clindamycin [10-14].

Our clinical case coincides as regards etiology (traumatism) and clinical evidence, although the pathogenesis of presentation is different since the pneumomediastinum is caused by subcutaneous emphysema by disruption of the oropharyngeal membrane allowing the passage of ambient air into the retropharyngeal space producing [15]. The dissection of this until reaching the upper mediastinum, which is achieved due to the pressures of ambient air that are greater than the internal pressures. Also the tools used for diagnosis and conduct are in accordance with those recommended by this academy.

\section{Conclusion}

Emphysema in deep spaces of the neck, are rare. In most cases emphysema is spontaneously reabsorbed, however, the patient should be kept under observation to reduce complications; As well as administration of analgesia and prophylactic antibiotic therapy.

\section{References}

1. Carlos Hidalgo (2014) Recurrent idiopathic subcutaneous emphysema. Case report. Journal of Medicine Universidad de los Andes, Merida Venezuela. 23(1).

2. José Antonio Hernández Aranda (2016) Correlation of findings by conventional radiology and computed tomography in mediastinal extension secondary to deep neck abscess: usefulness of chest X-ray. Annals of Radio Mexico 3: 167-173.

3. Anguita Sánchez I (2010) Cervicofacial emphysema as a complication of oral maneuver. Spanish Society of General and Family Physicians 128: $240-242$.

4. Petersilka (2011) Subcutaneous emphysema in periodontal treatment. Spanish Society of Periodontics and Osseointegration 21(1): 21-28.

5. Caliento R (2011) Cervical and retropharyngeal emphysema after maxillofacial trauma. Rev Odontol UNESP 40: 77.

6. Abad Royo Jm (2014) Spontaneous massive cervical emphysema. Aragonese Society of Otorhinolaryngology 17(2): 9-10.

7. Ana Belén, Aláez CH (2009) A case of spontaneous pneumomediastinum that simulates a syndrome of Boerhaave. Rev Chilena of Surgery 61(1): 89-91.

8. Claudio Andrés Gamboa Vidal, Carlos Andrés Vega Pizarro, Andrés Almeida Arriagada (2006) Subcutaneous emphysema during restorative treatment: clinical case. AvOdontoestomatol 22(5): 1-3.

9. F Ruiz-Ruiz, A Sampériz, T Rubio, F Escolar (2006) Spontaneous pneumomediastinum. Anales Sis San Navarra 29(2).

10. Giancarlo Baldini P (2002) Emphysema surgery. GacMéd Caracas $110(1)$.

11. Alarcón, Kevin Gustavo (2014) Treatment of severe subcutaneous emphysema by microdrainage. About a case. Arch Bronconeumol 50(1): 47-48.

12. Rodríguez Pérez, Miguel Alberto (2014) Spontaneous pneumomediastinum after tuscidal efforts. Otorrinolaringología e cirugíacérvico-facial 52(3).

13. López-Peláez MF, Roldán J, Mateo S (2001) Cervical Emphysema, Pneumomediastinum, and Pneumothorax Following Self-induced 
Oral Injury: Report of Four Cases and Review of the Literature. Chest 120(1): 306-309.

14. Carrillo Esper Raúl (2008) Pneumomediastino y pneumoperitoneo secundarios a efecto Macklin. Revista de la Asociación Mexicana de Medicina Crítica y Terapia Intensiva 22(2): 111-114.
15. Peña, Troncoso y Defillo (1979) Enfisema intersticial. A propósito de 24 casos del Hospital Infantil Robert Reid Cabral. Acta Medica Dominicana.

Your next submission with Juniper Publishers will reach you the below assets

- Quality Editorial service

- Swift Peer Review

- Reprints availability

- E-prints Service

- Manuscript Podcast for convenient understanding

- Global attainment for your research

- Manuscript accessibility in different formats ( Pdf, E-pub, Full Text, Audio)

- Unceasing customer service

Track the below URL for one-step submission https://juniperpublishers.com/online-submission.php 